\title{
Kırşehir İlinde Köy Adlarının Coğrafi Açıdan Değerlendirilmesi
}

\section{Geographical Evaluation of Village Names in Kırşehir Province}

\author{
Okan TÜRKAN ${ }^{1}$ (1) \\ ${ }^{1}$ Çankırı Karatekin Üniversitesi, Edebiyat Fakültesi, Coğrafya Bölümü, Çankırı, Türkiye
}

ORCID: O.T. 0000-0002-5575-0322

\section{öz}

Dünyadaki tüm topluluklar kendilerini yoğuran kültür ikliminden çevreye bakar ve o çevreyi anlamlandırır. Topluluklar ve/veya milletler, kendilerini özgün yapan kültür ikliminin referansları ile düşünür, yaşar ve geleceği tasarlar. Milletler bu kültür iklimi içerisinde yaşadıkları coğrafyayı değerlendirirler. Fiziki coğrafyayı, çeşitli biçimlerde beşeri coğrafyaya dönüştürürler. Bu işi, doğayı dönüştürerek yaptıkları gibi doğayı adlandırarak da yapmaktadırlar. Dünyadaki yeri çok geniş olan kadim Türk kültürü de yaşadığı arazileri adlandırarak yurt kılmıştır. Bin yıldan fazladır Anadolu’yu yurt edinen Türkler burayı büyük oranda öz kültürlerinin etkisiyle kendi sözcükleriyle adlandırmışlardır. Bu araştırma Kırşehir ilinde yer alan köylerin adlandırılmasında hangi faktörlerin esin kaynağı olduğunu ortaya koymayı amaçlamaktadır. Kırşehir'de köy adlarının tespitine yönelik olarak bölgenin tarihi geçmişi ve dil özellikleri açısından araştırmanın sonuçlanmasına katkı sunabilecek ilgili literatürün değerlendirilmesinin yanında, saha gezileri gerçekleştirilmiş ve gözlemler yapılarak ayrıca yöre sakinlerinden de bilgi edinilmeye çalışılmıştır. Bu çalışmaların sonucunda bulgular coğrafya disiplinin gözüyle değerlendirilerek kategorize edilmiş ve köy adları beş ayrı sınıfa bölünmüştür. Nitekim Kışsehir ilinde yer alan toplam 255 köy adının \%25'inin doğal coğrafya, \%64'ünün ise beşeri coğrafya özellikleriyle ilgili olduğu ortaya çıkmıştır. Doğal coğrafya özellikleri içerisinde hidrografyanın, beşeri coğrafya içerisinde ise boy, aşiret, cemaat ve önemli şahıslara ait isimlerin köy adlarının kaynağı olduğu görülmüştür.

Anahtar kelimeler: Coğrafya, toponimi, Kırşehir ili

\section{ABSTRACT}

Communities and/or nations transform physical geography into human geography in various forms. They do this by transforming nature as well as by naming nature. The Turks, who have made Anatolia a homeland for more than a thousand years, have named this place with words that reflect their core culture. This research aims to explain which factors have been involved in naming the villages in Kırşehir. The literature reflecting the region's historical background and language characteristics was reviewed to inform the analysis of village names in Kırşehir. In addition, trips and observations were made and information was also obtained from local residents. Therefore, the study findings were categorized according to geographical discipline and the village names were divided into five categories. Results revealed that $25 \%$ of the 255 village names in Kırşehir province are related to physical geography and $64 \%$ are related to human geography. Hydrography was a physical geographic feature used to create village names. In human geography terms, the names of tribal, communities, and important individuals were the source of village names.

Keywords: Geography, toponymy, Kırşehir province

Başvuru/Submitted: 03.04.2020 • Revizyon Talebi/Revision Requested: 31.05.2020 • Son Revizyon/Last Revision Received: 17.06 .2020 • Kabul/Accepted: 06.07.2020 - Online Yayın/Published Online: 10.12.2020

Sorumlu yazar/Corresponding author: Okan TÜRKAN / okanturkan@karatekin.edu.tr Atıf/Citation: Turkan, O. (2020). Kırşehir ilinde köy adlarının coğrafi açıdan değerlendirilmesi. Cografya Dergisi, 41, 61-75. https://doi.org/10.26650/JGEOG2020-0029 


\section{EXTENDED ABSTRACT}

All the communities in the world look at the environment according to their culture and make meaning from a sense of place. Communities and nations think, live, and design the future with cultural references that make them unique. Nations evaluate their geography according to their specific culture. They transform physical geography into human geography in various forms. They do this by transforming and naming nature. In general, geography researches the relationship between human beings and space. One of the topics that we can see clearly in this relationship is toponyms. Toponyms are the most characteristic evidence of human interaction with the geographical environment (Erinç 1989: 9). Toponyms also reveal a country’s past, present, and future. Analyzing a place name, which is its most important and distinctive feature, provides an understanding of the accumulated historical, political, cultural identity of that place.

Turks have given names to places that reflect their identification with the geography they live in. They have named their new homeland sometimes after the name of their old homeland, and sometimes after tribes and communities, or important people (Durbilmez ve Tekin, 2014: 118; Eröz, 1984: 43; Tarım, 1940: 293; Yediyıldız, 1984: 27). Additionally, Turks have used plant and animal names, which are ancient Turk totems, or referred to the natural geographical characteristics of the area to create settlement names. Studies of toponymy began in the first half of the 20th century in Turkey. These studies started a little later than in other countries in Europe. However, during the second half of the Republic, the importance of these studies was noticed and increased. Toponymy is very important because the study of place names provides information about a region's history, social, and cultural identity, and the geographical structure of that region. In this context, naming is very important for keeping social memory alive and transmitting the sociocultural structure and national culture to the future.

Since all human activities occur at a geographical location, the physical and human geography features of a place are often the most influential toponym factors in that area. Therefore, geography is naturally central to toponymy sciences. However, geographers' methods for studying the subject are different from other disciplines. Geographers often classify place by identifying the physical and human factors affecting naming.

In this context, this research aims to explain what factors were involved in naming the villages in Kirşehir. It aimed to group the village names in Kırşehir province according to the natural and human geographic characteristics of the region and other reasons. In addition, it is hoped that knowledge and attachment to place will therefore be improved in Kırşehir, contributing to cultural continuity.

The current names and numbers of the villages within the scope of the research have been accessed from the Ministry of the Interior website. The literature reflecting the historical background and language features of the region was examined to analyze village names in Kırşehir. Studies of Turkish tribes and communities by Turkay (2001), Halaçoğlu (2009), and Uçakçı (2015) also provided important information. In addition, the Compilation Dictionary was used, a Turkish Language Institution publication. While determining the source of village names in Kırşehir province, difficulties emerged interpreting the meanings of some village names. In addition, trips and observations were made and information was obtained from local residents to determine the meaning of these village names.

There are 255 villages in the Kırşehir province. Human geography features mostly determined village names in Kırşehir, and historical background had the least effect. We found that $64 \%$ of the 255 village names are related to human geography and $25 \%$ are related to physical geography. Although natural factors have an effect, the findings indicate that human factors dominate place naming. There are nine village names related to place and location features in Kırşehir, and seven village names related to historical background. Finally, the study found 12 villages that could not be classified since the source of the name could not be determined. Therefore, the sources of $95 \%$ of village names in the province were identified. 


\section{GÍRIŞ}

Genel olarak ifade edilirse coğrafya insan ile mekân arasındaki ilişkinin araştırılmasıdır. Bu bağlamda söz konusu ilişkiyi keskin bir biçimde görebileceğimiz yerlerden biri de toponimler yani yer adlarıdır. İnsanların yeryüzünde biyolojik varlığını devam ettirmek amacıyla gerçekleştirdiği temel faaliyetler içerisinde yeme içmenin yanı sıra barınma yani yerleşme faaliyeti de bulunur. Yerleşme faaliyeti, insanların her türlü ihtiyaçlarını giderebilecekleri en uygun yaşam alanlarını ve buralara yerleşmelerini ifade eder (Özçağlar, 2009: 74). Yerleşilen yerler rastgele seçilen alanlar olmayıp gerek doğal gerekse de beşeri ihtiyaç ve arzuları doğrultusunda yer seçimi yaparak insanlar, çeşitli nitelikte yerleşim birimleri kurmuşlar ve adlandırmışlardır. Bu bağlamda adlandırma insanın en eski eylemlerinden biri olup yaşadığı coğrafyayı tanımlamak ve diğgerlerinden ayırt etmek için kullanageldiği bir olgudur (Şahin ve Köse, 2014: 172). Başka bir deyişle yer adları insanın coğrafi ortamla bütünleşmesinin en karakteristik nişanesidir (Erinç, 1989: 9). Toponimler bir kültürel coğrafi görünümdeki en önemli özelliklerden birisi olup o yerin neresi olduğunun yanında nasıl bir yer olduğuyla ilgili bazı ipuçlarını da barındırabilmektedir (Tümertekin ve Özgüç, 2002:196). Bu anlamda toponimi diğer deliller ortadan kalkmış olsa bile o yere hangi insanların yerleştiklerini açıklayarak tarihselliğini ortaya koyabilmektedir (Tümertekin ve Özgüç, 2002:197). Toponimler bir ülkenin geçmişi, bugünü ve aynı zamanda geleceğidir. Bir halkın milli ve aynı zamanda manevi serveti olan ve coğrafi adlar olarak da tanımlanabilen toponimler herhangi bir yere sebepsiz ve tesadüfi olarak verilmemiştir. $\mathrm{Bu}$ süreç insanın coğrafi ortamla kurduğu ilişkiyi yansıtan bilinçli bir üretimdir (Yusifov ve Kerimov, 2017: 17). Bilince içkin söz konusu durum özellikle sömürgecilik döneminde yeni dünya karalarının yeniden adlandırılmasıyla neredeyse doruk noktasına çıkmıştır. Sömürgeci güçler ele geçirdikleri topraklara kendi dilleri ve ülkelerindeki adları vermek suretiyle o yerin yeni mülkiyetini deyim yerindeyse ilan etmekteydiler (Özgüç ve Tümertekin, 2012:59).

Yer adları; toplumların coğrafi ortamla kurdukları ilişkinin tarihi kayıtlarını sunarlar. Halklar kendi kültürel kimliklerini, yer/ler (i) adlandırmak suretiyle damgalamış ve bu yolla da başta yerleşim birimleri olmak üzere tüm coğrafi ortamı kendilerinin kılmışlardır (Gülbetekin, 2017: 19). Bir mekânın en önemli ayırt edici özelliği olan adının çözümlenmesi o mekânın tarihi, siyasi, kültürel kimliği ve birikimlerinin aydınlatılmasını sağlar (Yavuz ve Şenel, 2013: 2241-2242; Güner vd., 2000: 283; Bulut, 1996: 30; Uygur, 1967: 502). Yer adlarından o yerin coğrafi özellikleri anlaşılabildiği gibi o adı veren toplumun değerleri, inançları ve yaşanmışlıkları da anlaşılabilmektedir.

Yer adları ait oldukları toplumların etnik kökenleri, kültürel havzaları, dil özellikleri, gündelik yaşamları, inançları ve değer yargıları gibi birçok özelliği yansıtan bilgiler içermektedir. Yer adlandırılmasının bu şekilde çok yönlü olması birçok bilim alanının bu konuyla ilgilenmesinin önünü açarak toponiminin interdisipliner bir yapıya sahip olmasını sağlamaktadır. Yer adlarının incelenmesinde bu interdisipliner yapıdan dolayı başta coğrafya, dilbilimi ve tarih olmak üzere etnoloji, sosyoloji ve antropoloji gibi birçok bilim dalı emek vermektedir (Gülbetekin, 2017: 20).

İnsanoğlunun dünyadaki tüm faaliyetleri coğrafi bir mekânda gerçekleştiğinden ve bu mekânın fiziki ve beşeri özellikleri ilgili alandaki yer adlarına en fazla etki eden faktörlerin başında geldiğinden toponimi ile ilgili bilimlerin merkezi konumunda doğal olarak coğrafya bulunmaktadır. Ancak coğrafyacıların konuyu inceleme usulleri diğer bilim dallarından farklı olarak daha çok adlandırmaya etki eden fiziki ve beşeri faktörlerin neler olduklarını tespit ederek gruplandırılması şeklinde olmaktadır (Emiroğlu, 1984: 181-200; Erinç, 1989: 9-13; Güney, 1996: 619-630; İbret, 2003: 5380; Koca ve Yazıc1, 2011: 1-10; Koday, 2000: 221-253; Sar1, 2007: 487-501; Tunçel, 2000: 23-34; Yaşar ve Yaşar, 2010: 599-611).

Toponimi ile ilgili çalışmalar Türkiye'de cumhuriyetin ilk yıllarında başlamış olmakla birlikte özellikle 1960'l1 yıllardan itibaren yapılan çalışmaların sayısında ciddi bir artış olduğu söylenebilir (Şahin, 2010: 135). Ancak bu çalışmalar içerisinde coğrafya disiplininin payının yeterli olduğu söylenemez. Coğrafya disiplinin toponimi alanına katkısı bağlamında çalışma alanı olarak Kırşehir belirlenmiştir. Kırşehir Orta Anadolu'da yer alan ve ilk iskân izlerine Kalkolitik Çağda rastlanmış, İlk Tunç Çağından itibaren önemli bir gelişme gösteren iskân faaliyetleriyle insanoğlunun yerleşim alanı olarak benimsediği ve yurt edindiği bir bölgedir. Bu bağlamda Kırşehir; bir yönetim etrafında siyasi olarak toplanmanın görüldüğü ilk tunç çağının ikinci yarısından itibaren Hitit, Firig, Pers, Kapadokya, Roma ve Bizans dönemlerinde önemli bir merkez olmuş daha sonra ise Malazgirt Savaşı ile birlikte Türklerin eline geçmiştir (Özüçetin vd., 2014: 596).

Yerleşme tarihinin çok eskilere dayanmasına ve Anadolu'da Türk kitlesel göçünün görece geç olmasına rağmen yer adlarının büyük bir kısmının Türkçe olmasında siyasi olarak Selçuklu ve Osmanlı gibi güçlü ve büyük Türk devletlerinin önemli payları vardır (Emiroğlu, 1984: 182). Nitekim Malazgirt öncesindeki akınların da izlerini taşımakla birlikte 1071 'den itibaren kitlesel 
nitelik kazanan Türk göçü Anadolu'nun geri kalanında olduğu gibi pek çok yer adını Türkçeleştirerek Kırşehir'in de vatanlaşmasını sağlamıştır (Baykara, 1984: 266). Bu yapılırken bazen yer adı tamamen değiştirilmiş bazen de yabancı kökenli bir yerleşme ismi Türkçenin ses özelliklerine uydurulmuş veya dildeki öğelerle değiştirilip yerlileştirilmiştir (Umar, 1993: 831).

Toplumların kültür hazineleri içerisindeki değerlerinden biri olan yer adları, bağlı oldukları toplumların geçmişini hafızalarında canlı tutup toplumun yaşadığı coğrafyayı vatan haline getirerek geleceğe taşınmasında önemli bir rol oynar (Hanilçe, 2013: 89; Yıldırım, 1984: 164). Bu bağlamda Türkler yaşadıkları coğrafyaya kendi kimliklerini yansitan adlar verirken yurt edindikleri yeni yerlere bazen eski yurtlarının adını, bazen de kendi oymak, aşiret ve cemaatleri ile önemli şahısların adlarını vermişlerdir (Durbilmez ve Tekin, 2014: 118; Eröz, 1984: 43; Tarım, 1940: 293; Yediyıldız, 1984: 27). Bunların dışında sahanın doğal coğrafya özellikleriyle eski totemik izleri taşıyan bitki ve hayvan adlarını da yerleşme adı olarak vermişlerdir.

\section{AMAÇ, YÖNTEM VE VERI}

Türkiye'de çeşitli zamanlarda birbirinden farklı disiplinlerin köy adları üzerinde yaptıkları araştırmalarda köy adlarını sınıflandırırken değişik şekillerde sınıflama yaptıkları görülmektedir. Ancak daha önce coğrafya disiplininin araştırmacıları tarafından yapılan birçok araştırma incelendiğinde yaptığımız çalışmada olduğu gibi köy adlarında genel olarak beşeri ve fiziki coğrafya faktörlerinin belirleyici olduğu tespit edilmiş ve çalışma bu temel üzerine inşa edilmiştir. Bu bağlamda çalışma Kırşehir ilinde yer alan köylere ad verilmesinde aşağıdaki sorulara cevap aranmıştır:

Doğal Coğrafya İle Köy Adları arasında ilişki var mıdır?

Beşeri Coğrafya Özellikleri İle Köy Adları arasında ilişki var midır?

Yer ve Konum Özellikleri İle Köy Adları arasında ilişki var midır?

Tarihsel Geçmiş İle Köy Adları arasında ilişki var mıdır?

Diğer Özellikler İle Köy Adları arasında ilişki var mıdır?

Dolayısıyla yapılan çalışma adlandırmada rolü olan sebeplerin gruplanarak hangi düzeyde etki ettiğini tespit etmeye yönelik olarak hazırlanmıştır. Bunun yanında yapılan çalışmayla köy adları değerlendirilerek Kırşehir'de mekân algısı, mekân bilgisi ve mekânsal aidiyet duygusunun geliştirilebileceği umularak kültürel devamlılığa katk1 sağlanması amaçlanmıştır.
Çalışmanın evreni Kırşehir ilinde yer alan ve tüzel kişiliği devam eden 255 köy oluşturmakta olup köy bağlıları ve daha önce köy tüzel kişiliği bulunan yerleşmeler çalışmaya dâhil edilmemiştir. Araştırma kapsamındaki köylerin güncel ad ve sayılarına İçişleri Bakanlığının Mülki İdare Bölümleri e-İçişleri Projesi sisteminden ulaşılmıştır. Kırşehir'de köy adlarının tespitine yönelik olarak bölgenin tarihi geçmişi ve dil özellikleri açısından araştırmanın sonuçlanmasına katkı sunabilecek ilgili literatür incelenmiştir. Bu kapsamda özellikle adlandırmada önemli oranda etkisi bulunan Türk boy, oymak, aşiret ve cemaatlerle ilgili olarak Türkay (2001), Halaçoğlu (2009) ve Uçakçı (2015)'nın araştırmaları yol gösterici olmuştur. Bunun dışında Türk Dil Kurumu yayınlarından olan, Derleme Sözlüğü’nden de yararlanılmıștır. Türkçede sözcükler yapı bakımından basit türemiş ve birleşik sözcükler olmak üzere üç ana grupta incelenir. Çalışma alanında her üç gruba giren köy adları mevcuttur. Basit ve türemiş sözcüklerden oluşan köy adlarının sınıflanmasında doğrudan sözcüğün kökü dikkate alınmışken birleşik sözcüklerden oluşan köy adlarındaki sözcüklerin sınıflandırılmasında anlambilimsel ve dilbilgisel ilişkiler belirleyici olmuştur. Bu durumda birleşik sözcüklerde baş ögenin kendisi önem taşımaktadır. Birleşik sözcüklerde anlam yönüyle yönetim görevini üstlenen ve kuruluşun ortaya çıkardığı genel anlamın çekirdeğini oluşturan baş ögedir. Türkçe öbek yapılarda ve birleşiklerde baş genellikle sağda bulunur ve baş ögenin solundaki diğer ögeler başı çeşitli açılardan niteler, tamamlar veya sinırlandırır (Sarı, 2016: 204). Fakat Çiftlikmehmetağa köyünde olduğu gibi isnat öbeği yapısındaki bazı birleşik sözcüklerde başın solda bulunması durumu da görülebilmektedir. Ancak bu, Türkçenin genel bir eğilimini göstermez. Zira böyle bir oluşum sözdizimsel açıdan da Türkçenin genel özelliklerini yansıtmaz (Sarı, 2016: 205). Birleşik sözcüklerin bileşenleri arasında yöneten-yönetilen ilişkisi vardır. Bunun yanında birleşik sözcükler sıralı birleşikler biçiminde de olabilirler ve bu birleşiklerde bileşenlerin biri diğerini nitelemez, eşit bir şekilde birleşirler (Çürük, 2017: 97; Sarı, 2018: 1255). Bir başka deyişle yöneten-yönetilen ilişkisi yoktur. Yani iki bileşenin anlamı birbirini tamamlar, ama birbirini yönetmez. Çalışma alanında bu özelliğe sahip olan bir köy adı yoktur. Bu bağlamda çalışma alanındaki birleşik ada sahip köy adlarının sınıflandırılmasında başöge merkeze alınmış ve saha çalışmalarıyla yapılan mülakatlarla da sınıflama nihayete erdirilmiştir. Birleşik ada sahip olan köyler tablolaştırılarak bulgular kısmının sonunda ayrıca değerlendirmeye alınmıştır. Kırşehir ilinde yer alan köy adlarının kaynağı belirlenirken zaman zaman bazı köy adlarının anlamlarının tespitinde bir takım zorluklar ortaya çıkmış ve bu durumun aşılması adına bu köy adlarının anlamlarının belirlenmesi için saha gezileri gerçekleştirilmiş ve gözlemler yapılarak ayrıca yöre sakinlerinden de bilgi edinilmeye çalışılmıştır. 
Türkiye'de köy adlarının önemli bir kısmında 1940 yılından günümüze kadar değişikliğe gidilmiş ve yeni isimler verilmiştir. Bu değiştirme işlemleri hem adının kökeni Türkçe olan hem de Türkçe olmayan köylerde birçok sebebe dayandırılarak yapılmıştır (Tunçel, 2000: 23). Çalışmada söz konusu değişikliğin yapıldığı 21 köy bulunmaktadır. Eskiden kullanılan söz konusu adların kökeni de araştırılarak açıklığa kavuşturulmaya çalışılmıştır.

\section{BULGULAR}

\subsection{Araştırma Alanındaki Köy Adlarının Genel olarak Sinıflandırılması}

Araştırma kapsamında Kırşehir ilinde yer alan toplam köy sayısı 255'tir. Kırşehir ilindeki köy yerleşmelerinin adlandırılmasında ağırlıklı olarak beşeri coğrafya özellikleri etki etmiş, en az ise tarihsel geçmişle ilişkili bir adlandırma kullanılmıştır (Tablo 1). Toplam 255 olan köy sayısının \%64'ünün beşeri coğrafya ile \%25'inin doğal coğrafya ile ilgili olması doğal faktörlerin etkisi olmakla birlikte adlandırma konusunda sahada asıl olarak beşeri şartların egemen olduğunu göstermektedir. Nitekim ilin bütünündeki yarı kurak iklim şartları dışında doğal coğrafya özellikleri bağlamında insan yaşamını etkileyecek önemli bir parametre bulunmaması bu durumu açıklamaktadır. Kırşehir ilinde yer ve konum özellikleri ile ilişkili 9, tarihsel geçmiş ile ilişkili olarak da 7 köy adı bulunmaktadır (Şekil 1). Yapılan inceleme sonucunda adın

Tablo 1: Köy yerleşme adlarının genel olarak sınıflandırılması. Table 1: General classification of village names.

\begin{tabular}{lcc}
\hline Kategoriler & Köy Sayısı & Oranı \\
\hline Doğal Coğrafya İle İlişkili Köy Adları & 63 & 25 \\
Beşeri Coğrafya Özellikleri İle İliş̧kili Köy Adları & 164 & 64 \\
Yer ve Konum Özellikleri İle İlişkili Köy Adları & 9 & 3 \\
Tarihsel Geçmiş İle İlişkili Köy Adları & 7 & 3 \\
Diğer Özellikler İle İlişkili Köy Adları & 12 & 5 \\
Toplam & $\mathbf{2 5 5}$ & $\mathbf{1 0 0}$ \\
\hline
\end{tabular}

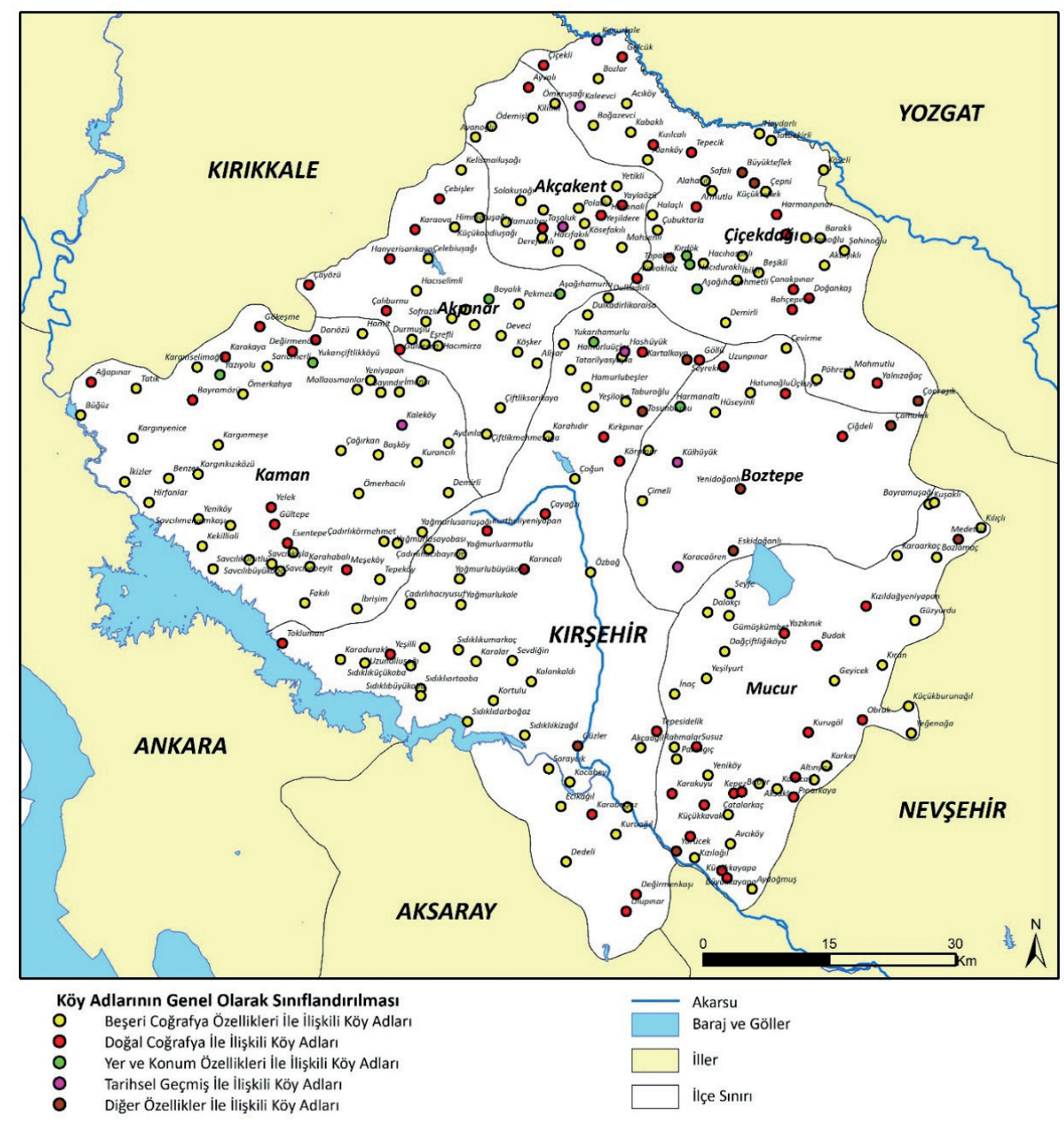

Şekil 1: Köy yerleşme adlarının genel olarak sınıflandırılması.

Figure 1: General classification of village names. 
kaynağı tam olarak kesinlik kazanmadığından tasnif edilememiş 12 köy yerleşmesi bulunmaktadır. Bunların bir kısmıyla ilgili fikir bulunmakla birlikte bazılarının adının kaynağıyla ilgili hiçbir veriye rastlanılamamıştır. Bu haliyle ildeki köy adlarının \%95'inin kaynağı tespit edilmiştir.

\subsubsection{Doğal Coğrafya Özellikleri ile İlişkili Köy Adları}

İnsan coğrafyanın yoğurduğu bir hamurdur. Bundan dolay1 insanlık tarihinde doğal şartlar, insan ve faaliyetlerinin ana belirleyicisi olmuştur. Ancak zaman içerisinde doğal coğrafya şartlarından doğrudan etkilenen insan, doğal ortamı değiştiren ve köklü dönüşümünü sağlayan bir figür haline gelmiştir. Bir başka deyişle insan ile doğal ortam arasındaki ilişkide, insan zamanla edilgen konumundan etken konumuna erişmiştir. Buna rağmen insanın eriştiği bilgi birikimi ve yetenekleri ile teknik kapasitesi inanılmaz bir seviyeye yükselse de dünyada ama az ama fazla oranda doğal şartların belirleyiciliği devam etmektedir.
Bu belirleyicilik bazı yerlerde baskın bir şekilde bazı yerlerde ise daha silik bir vaziyette görülmektedir. Bu durumun bir yansıması olarak doğal coğrafya şartlarındaki yoksunluk ve/veya varsıllık köy adlarına esin kaynağı olabilmektedir. Nitekim su kaynaklarının az veya çok olduğu yerde bu durumu anlatan köy adlarının, ormanlık veya çalılık bölgelerde bitki adları alan köylerin bulunması bu ilişkiyi net bir biçimde anlatmaktadır.

Kırşehir ilindeki 63 köyün adının kaynağı doğal coğrafya şartları olup bu durum tüm köy adların \%25'ini oluşturmaktadır. Bir başka söylenişle ildeki her dört köyün birinin adının kaynağını doğal coğrafya şartları veya süreçleri oluşturmaktadır.

Doğal coğrafya ile ilişkili köy adları içerisinde en fazla sayı hidrografyayla ilgili adlandırmalarda bulunmaktadır (Şekil 2). Bunu sırasıyla biyocoğrafya ve jeomorfolojiyle ilişkili köy adları takip etmektedir. En az adlandırma litoloji ve klimatolojiyle ilgilidir (Tablo 2).

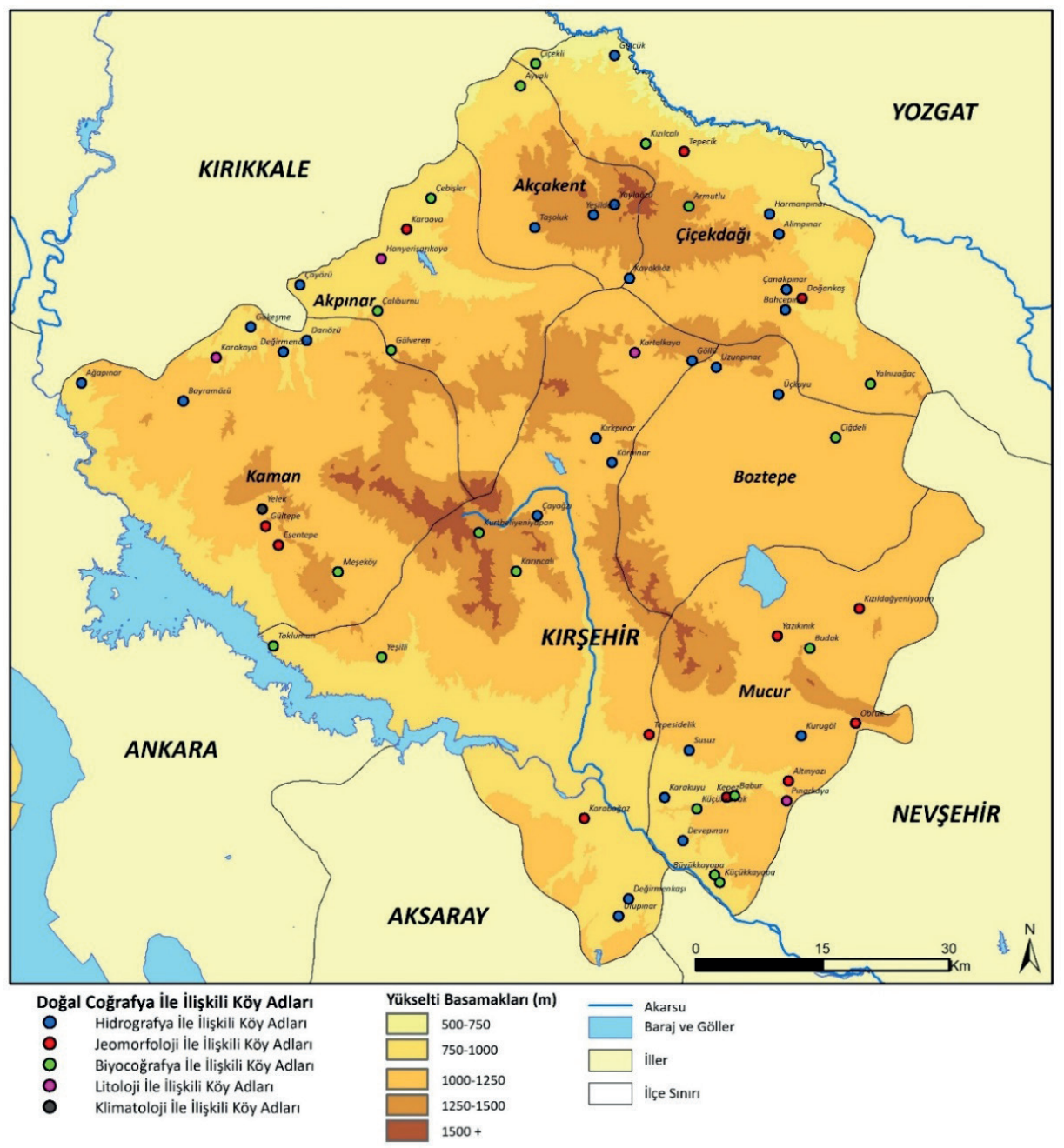

Şekil 2: Doğal Coğrafya İle İlişkili Köy Adları.

Figure 2: Village names related to physical geography. 
Tablo 2: Doğal Coğrafya İle İlişkili Köy Adları Table 2: Village names related to physical geography

\begin{tabular}{lcc}
\hline Doğal Coğrafya İle İlişkili Köy Adları & Köy sayısı & Oranı \% \\
\hline Hidrografya İle İlişkili Köy Adları & 27 & 43 \\
Biyocoğrafya İle İlişkili Köy Adları & 19 & 30 \\
Jeomorfoloji İle İlişkili Köy Adları & 12 & 19 \\
Litoloji İle İlişkili Köy Adları & 4 & 6 \\
Klimatoloji İle İlişkili Köy Adları & 1 & 2 \\
Toplam & $\mathbf{6 3}$ & $\mathbf{1 0 0}$ \\
\hline
\end{tabular}

\subsubsection{Hidrografya İle İliş̧kili Köy Adlar}

$\mathrm{Su}$, insanoğlunun biyolojik varlığını devam ettirmesi için vazgeçilemez ve yeri doldurulamaz bir kaynaktır. Bundan dolayıdır ki yerleşmiş olduğu sahaları daima su kaynaklarıyla doğrudan ilintili olmuş olan insanoğlu, yerleşme yeri seçiminde su temininin sorunlu olmadığı veya nispeten az olduğu yerleri tercih etmiştir. İnsan yaşamını doğrudan etkilediğinden, başta yerleşim yerleri olmak üzere beşeri faaliyetlerin yürütüldüğü tüm sahalarda göl, akarsu, dere ve kaynak gibi hidrografik unsurlar adlandırmada kullanılmıştır. Su kaynaklarının az olduğu kurak ve yarı kurak bölgelerde suyun ehemmiyeti daha fazla görünür durumdadır. Nitekim Türkiye'nin kuzey kesimindeki sınırlı bir saha dışında büyük oranda Akdeniz yağış rejimi hâkim durumda olup yaz dönemi çeşitli seviyelerde kurak geçmektedir. Dolayısıyla su kaynaklarının çok büyük bir öneme sahip olduğu bu gibi kurak yerlere yerleşenler yerleşmelerine ad olarak buradaki su kaynağını verebilmektedirler (Koca ve Yazıc1, 2011: 8).

Kırşehir ilinde 27 köy adının hidrografya ile ilişkili olduğu görülmektedir. Doğal coğrafya elemanları içerisinde en fazla oranı $\% 43$ ile hidrografya unsurlarının oluşturması adlandırmada su ile olan etkileşimin önemli olduğunu göstermektedir. Nitekim ilin tamamında karasal iklim şartlarının gözükmesi ve bunun sonucunda yağış miktarının ve su kaynaklarının yetersiz olması adlandırmada suyun önemini vurgulamaktadır. Ancak burada belirtilmelidir ki tarihi süreç içerisinde ildeki 21 köyün adı değiştirilmiş ve bunların yedisine hidrografya ile ilişkili adlar verilmiştir. Bu köyler; Cemele-Çayağzı, Küngüş - Harmanpınar, Merdeşe - Bayramözü, Merdaneli - Çayözü, Tatarlar-Gökeşme, Hırali - Değirmenkaşı ve Sulhanlı - Ulupınar köyleridir. Köy adlarındaki değişime gidilmesinin birçok sebebi olmakla birlikte en çok da değişiklik Türkçeleştirme gerekçesiyle yapılmıştır (Tunçel, 2000: 27-28). Ancak bu süreçte bazı köylerin adı Türkçe olduğu halde, Türk boy, oymak, aşiret ve cemaat adı almasına rağmen adlandırmada değişikliğe gidilerek bazı hataların yapıldığ1 görülmektedir. Söz konusu köylere örnek olarak Tatarlar, Küngüş ve Cemele köyleri verilebilir.
Nitekim Tatarlar özellikle günümüz Rusya Federasyonu'nda olmak üzere birçok bölgede yurt tutmuş olan kadim Türk unsurlarındandır. Danışma yeri anlamına gelen Küngüş adının bu köyün ve civardaki beylerin kurultay, müşavere yeri olması muhtemeldir (Gündüz, 2006: 37). Cemele köyünün adı bir Türkmen aşireti olan İnallı aşiretinin bir kolu olan Cemele cemaatinden gelmiştir (Uçakçı, 2015b: 263-264).

Çevresine göre nispeten yüksek ve dağlık arazilerin bulunduğu yerlerde yağış, düz ve alçak sahalara nazaran daha fazla olmaktadır. Bu durum söz konusu kesimlerde yeraltı ve yerüstü suları bakımından görece daha elverişli bir ortamın oluşmasını sağlamaktadır. Bu bağlamda Kırşehir merkez, Kaman ve Çiçekdağı ilçelerinde yüksek ve dağlık araziler biraz daha fazla yer kapladığından bu kesimler Kırşehir ilinde hidrografik unsurların köy adı olarak en fazla kullanıldığı ilçelerdir. Nitekim saha gezileri sırasında Çayağzı, Alimpınar, Bahçepınarı ve Gökeşme köylerinde gözlemlediğimiz gibi çevresine göre yüksek ve kayalık alanların bulunduğu bu yerleşmelerde su kaynakları diğer yerlere göre daha fazladır.

Yer altı sularının yerüstüne çıktığı yere Türkiye'de genellikle kaynak denilmekle beraber kaynak anlamında çeşitli yörelerde pınar, kuyu, bulak, göze, eşme, memba gibi sözcükler de kullanılmaktadır (İzbırak, 1989: 117). Kırşehir yarı kurak bir bölgede yer aldığından insanların önemli bir kısmı su ihtiyacını bu kaynaklardan karşılamaktadır. Bu durumu yansıtacak şekilde hidrografyayla ilişkili köy adları içerisinde en fazla sayıda adında kaynak anlamında kullanılan pınar ve türevi bir ifade bulunan 14 köy yer almaktadır. Ülkemizde akarsuların su miktarına, yatak genişliğine veya boyutlarına göre su, oluk, öz, dere, çay, ırmak, nehir gibi isimler verilebilmekte ve bunların bazıları birbirlerinin yerine de kullanılabilmektedir (İzbırak, 1989: 117). Bu bağlamda akarsu anlamına gelebilecek biçimde isminde Çayağzı, Darı̈zü, Taşoluk ve Yeşildere köylerinde olduğu gibi dere, su, öz, çay, oluk geçen köy sayısı da fazladır.

\subsubsection{Biyocoğrafya İle İlişkili Köy Adları}

Doğal coğrafya ile ilişkili köy adlarında çalışma alanında ikinci sıray1 \%30'luk bir oranla biyocoğrafyayla ilişkili olanlar almaktadır. Bu köylerin ikisinin adı sonradan verilmiş olup bunlar eski adlarıyla Zekere - Yalnızağaç ve Sallak Çalıburnu'dur. Zekerhacılı adıyla da anılan Zekere köyü adının kurucuları Zekeriya Hacı Aşiretine bağlı olduğu düşünülmektedir (Uçakçı, 2015a: 315). Sallak adı TDK Derleme Sözlüğü'nde bozuk, çürük, çelimsiz, kasap, kasap çırağı olarak geçmekteyse de köyün eski adının kaynağına ulaşılamamıştır (TDK, 2009e: 
3528). Kırşehir ilinde 19 köy, adını biyocoğrafik unsurlardan almış olup bunların yedisi adını evcil veya yabani hayvanlardan, geri kalan 12 köy ise bitkilerden almaktadır (Tablo 2). Köy adının kaynağı hayvan adı olanlar; Babur, Büyükkayapa, Çebişler, Karıncalı, Kurtbeliyeniyapan, Küçükkayapa ve Tokluman'dır. Babur, TDK Derleme Sözlüğü'nde çok kuvvetli ve çevik olan, kaplana benzeyen bir hayvan olarak geçmektedir (TDK, 2009a: 454). Kayapa ise aynı kaynakta gri renkli yaban güvercini olarak geçmektedir (TDK, 2009d: 2698). Çebiş, bir yaşındaki keçi yavrusuna denir. Çebişler adı, köyün geçmişinde hayvancılı̆̆ın önemli olduğunu göstermekle birlikte köy adının Bayat Boyu Çebişli aşiretinden de gelme olasılığı bulunmaktadır (Uçakç1, 2015a: 179). Tohluman veya Tokluman bir yaşında doğuran koyundur (TDK, 2009e: 3946). Nitekim bölgede küçükbaş hayvancılığın yaygın olması köy adının kaynağının koyunla ilgili olması olasılığını artırmaktadır.

Kırşehir ilinde bitki türleri ile ilişkili 12 köyden sekizinin adı ağaç veya çalı türleriyle ilgilidir. Diğerlerinde ise ot türleri veya ot çağrışımına sahip olan sözcükler yer almaktadır. Çiğdeli, Kırşehir'de olduğu gibi ülkemizin bazı kesimlerinde hünnap ağacı anlamında kullanılmaktadır (Baytop, 2007: 71). Çalışma alanında çiğde, ayva ve armudun yerleşmelere isim olarak verilmesi geçmiş dönemdeki meyvecilik olgusunu anlatmaktadır. Günümüzde bu köylerde söz konusu faaliyet fazla yapılmamaktadır. Adını köy yakınlarındaki meşelikten alan Meşeköy'de geçmiş zamanda geniş alan kaplayan meşeler, insanların tahribi sonucunda oldukça azalmıştır. Neredeyse köyde meşe sadece yerleşmenin adında kalmıştır.

\subsubsection{Jeomorfoloji İle İlişkili Köy Adları}

Adı jeomorfolojik unsurlarla ilişkili olan köy sayısı 12 olup bunlar doğal coğrafyayla ilişkili köyler içerisinde \%19'luk bir paya sahiptir. Kırşehir genel olarak türdeş bir morfolojiye sahip olup ilde düzlük alanlar oldukça fazladır. Bir başka deyişle ildeki morfolojinin çeşitlilik göstermemesi jeomorfolojik unsurlarla ilişkili köy adı oranının bu denli az olmasında etkili olmaktadır. Nitekim çalışma alanında platoların fazla olması, dağlık alanların fazla yer kaplamaması morfolojik çeşitliliğin de az olduğunu göstermektedir. Daha önceleri kökenini belirleyemediğimiz Şiditler ismi değiştirilerek köyün adı Doğankaş olarak yenilenmiştir. Kaş ifadesi tepe dağ sarp kayalık anlamında kullanıldığı gibi su kaynağı anlamında da kullanılmaktadır (TDK, 2009d: 2677). Köyde kayalık alanların varlığı adının buradan aldığını göstermektedir. Adını Varsaklara bağlı bir aşiretten alan Aflak köyünün adı Altınyazı olarak değiştirilmişsir (Uçakçı, 2015a: 383). Yazı dilimizde düz yer, ova, kır anlamlarında kullanılmaktadır (TDK, 2009f: 4819). Bozkırla kaplı ve düzlüklerin bol olduğu bu köye Altınyazı adının verilmesi köyün doğal coğrafya özellikleriyle gayet uyumludur. Yine aynı ada sahip diğer bir köy ise Yazıkınık köyü olup buranın da morfolojik özellikleri Altınyazı ile aynıdır. Düzlük anlamında kullanılan ova kelimesi ise Karaova köyüne isim olarak verilmiştir. Boynuinceli Aşireti teşekkülü olan Savcılı aşiretinin kurduğu bir köy olan Savc1lpparsa köyünün adı daha sonra Gültepe olarak değiştirilmiştir (Uçakçı, 2015a: 324). Kırşehir genelde hafif tepelik alanlara sahip olan bir plato yüzeyi durumunda olduğundan jeomorfolojik unsurlarla ilişkili köy adlarında tepe sözcügü daha çoktur. Nitekim bu gruptaki 12 köy adının dördü (Esentepe, Gültepe, Tepecik ve Tepesidelik) tepe ile ilgilidir. Kayalık veya tepelik alanlar arasında kalan daha alçak alan halk arasında boğaz olarak adlandırılmaktadır. Nitekim Karaboğaz köyünde böyle bir arazi biçimi vardır. Obruk kısaca yeraltı boşluklarının çökmesiyle oluşmuş olan çukurluklar olup Obruk köyü adını bu çukurdan almaktadır. Kızıldağyeniyapan köyü ise adını köyün güneydoğusundaki Kızıldağ'dan almaktadır. Kepez halk ağzında mağara anlamına gelmekte olup köy adını burada bulunan mağaradan almaktadır (TDK, 2009d: 2748).

\subsubsection{Litoloji İle İlişkili Köy Adları}

Kırşehir ilinde litolojiyi yansıtan köy adı sayısı oldukça az olup bunların sayısı dörttür. Bu köylerin isimlerinin tamamında kaya sözcüğü geçmektedir. Bu grupta da ad değişikliği yaşanmış ve eski adı Kabaca olan köye Pınarkaya denmiştir. Çalışma alanındaki köylerde taş ve kaya isimleri gerek renk gerekse de diğer özellikleri ile birlikte kullanılmıştır. Bu bağlamda Karakaya ve Hanyerisarıkaya köylerinde renk ön planda olmuş, Kartalkaya'da ise köyün doğusundaki kayalıklara kartalların konmasıyla kayalıkların özelliği belirtilmiştir.

\subsubsection{Klimatoloji İle İliş̧kili Köy Adları}

Çalışma alanında doğal coğrafya ile ilişkili adlandırma içerisinde sadece Yelek köyünün klimatoloji ile ilişkili bir ada sahip olduğu görülmektedir. Yelek adı köyden aldığımız bilgiye göre rüzgârlı, yel alan anlamına gelmektedir. Nitekim köyün bir vadi içerisinde yer alması hava akımlarını kolaylaştırarak rüzgârlı olmasını sağlamaktadır.

\subsubsection{Beşeri Coğrafya Özellikleri ile İlişkili Köy Adları}

Kırşehir ilindeki 255 köyün 164'ü beşeri coğrafya ile ilişkili isimlere sahiptir (Tablo 3). Yani ildeki tüm köylerin \%64'ünün adının kaynağı beşeri coğrafya ile ilişkilidir. Bu kadar yüksek bir 
Tablo 3: Beşeri Coğrafya ile Illişkili Köy Adları. Table 3: Village names related to human geography.

\begin{tabular}{lcc}
\hline Beşeri Coğrafya İle İlişkili Köy Adları & Köy sayısı Oranı \% \\
\hline Boy, Aşiret, Cemaat ve Önemli Şahıslar İle İlişkili Köy Adları & 113 & 69 \\
Yerleşme Şekilleri İle İlişkili Köy Adları & 25 & 15 \\
Dini Unsurlar İle İlişkili Köy Adları & 12 & 7 \\
Sosyal ve Kültürel Değerler İle İlişkili Köy Adları & 11 & 7 \\
Geçim Kaynakları ve Meslekler İle İlişkili Köy Adları & 3 & 2 \\
Toplam & $\mathbf{1 6 4}$ & $\mathbf{1 0 0}$ \\
\hline
\end{tabular}

oran, çalışma sahasında beşeri süreçlerin ad verme konusundaki baskın yönünü ortaya koymaktadır. Beşeri coğrafya ile ilişkili adlar içerisinde en fazla boy, aşiret, cemaat, oymak ve önemli şahıslarla ilişkili olanlar yer almaktadır. Bu grupta yer alan köy sayısı 113 olup aynı kategoride en az rastlanılan köy adı türü ise geçim kaynakları ve meslekler ile ilişkili olanlardır (Şekil 3). Söz konusu grupta sadece 3 köy yer almaktadır.
Kırşehir ilinde bu grupta yer alan beş köyün adı çeşitli gerekçelerle değiştirilmiştir. Bunlar; Büyükkışla - Terziyanlı, Çubuktarla - Veletli, Yazıyolu - Hacıaraplı, Aydınlar - Sofular ve Yeşilyurt - Büyükköpekli köyleridir. Söz konusu köylerin eski adlarının tamamı bu köyleri kuran Türk aşiret ve cemaatlerin isimleridir. Bu bağlamda köy isimleri Türkçeleştirirken ne denli özensizlik yapıldığı görülmektedir.

\subsubsection{Boy, Aşiret, Cemaat ve Önemli Şahıslar ile İlişkili Köy Adları}

Beşeri coğrafya ile ilişkili köy adları içerisinde \%69 ile en yüksek oran boy, aşiret, cemaat ve önemli şahıslar ile ilişkili köy adlarındadır. Bu durum yerleşmelere ad verilmesinde sahiplenme ve aidiyet duygusunun ad verme usullerinde diğerlerinden daha fazla etki ettiğini keskin bir biçimde göstermektedir. İl veya ulus adı altında gruplandırılan konar-göçer Türkler sırasıyla boy

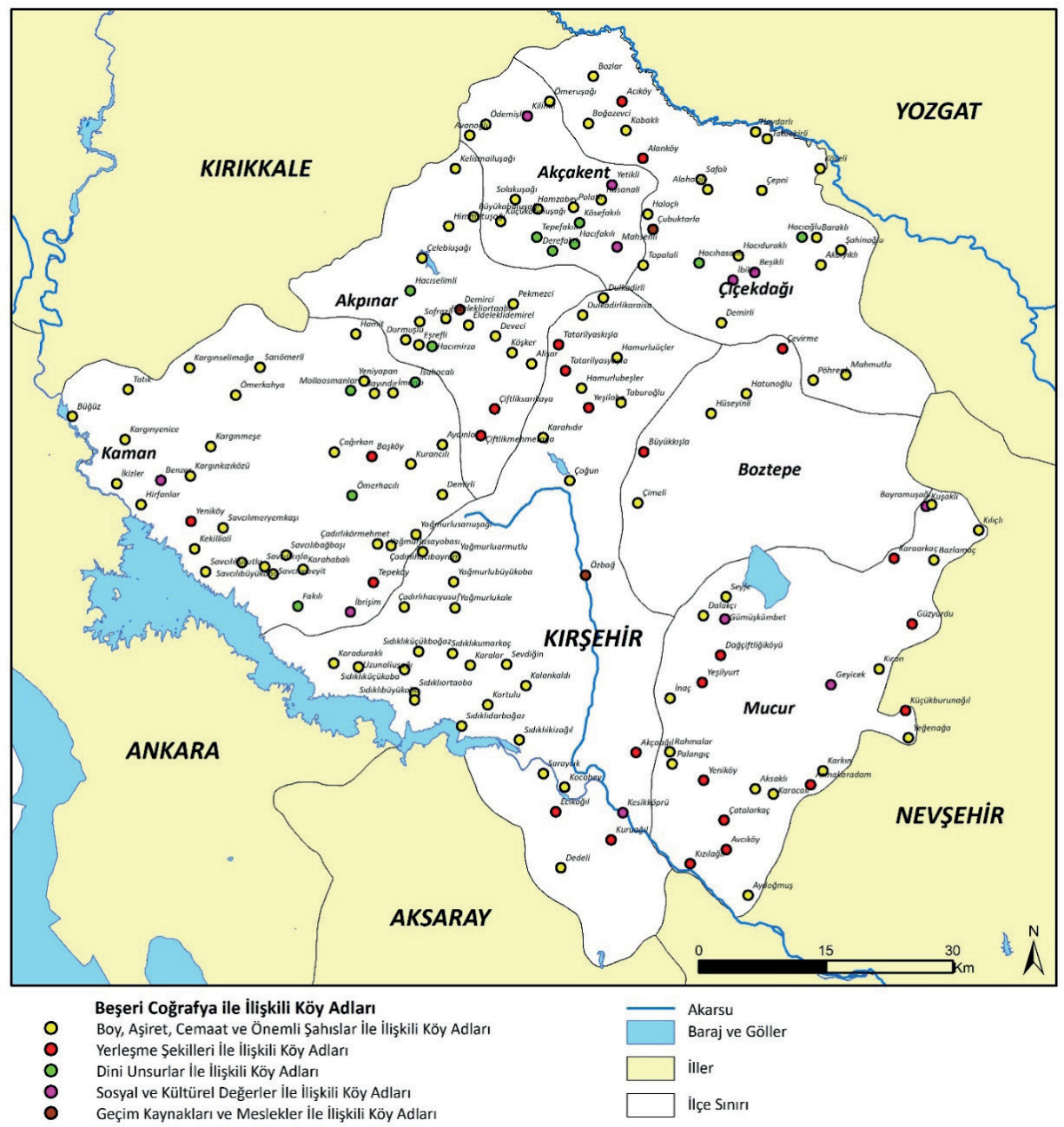

Şekil 3: Beşeri Coğrafya ile İlişkili Köy Adları.

Figure 3: Village names related to human geography. 
(kabile), aşiret, cemaat, oymak, mahalle ve oba (aile) şeklinde bölümlere ayrılmıştır (Halaçoğlu, 2009: XVII). Bin yılı aşkın süredir Anadolu'yu yurt tutmuş olan Türkler nicel anlamda birbirinden farklı büyüklükte gruplara ayrılarak zaman içerisinde yerleşik hayata geçmişler ve yerleştikleri birimlere de genellikle kendi mensubiyetini gösterecek biçimde boy, aşiret, cemaat veya oymaklarının isimlerini vermişlerdir. Çeşitli özellikleriyle öne çıkan bir kişinin adını bir yere bağlamak ve böylece o kişiyi ebedileştirmek birçok toplumda görülebilen bir durumdur (Sakaoğlu, 1984: 259). Bu bağlamda köy yerleşmeleri adını bir komutandan veya Türk aşiretlerince önemsenen bir kişinin adından da alabilmektedir (Koday, 2000: 236). Bunların yanında Anadolu'da kadı gibi halkın nezdinde bir karşılığı olan birçok şahsın ismiyle beraber unvanları da köylere isim olarak verilmiştir. Bu unvanlar arasında hacı, hoca, ahi, çelebi, pir, koca, gazi, veli, dede, şeyh, molla gibi sözcükler bulunmakta ve birçok köy adında bunlar geçmektedir (Gökmen, 2015: 41).

Malazgirt zaferinden sonra Selçuklular tarafindan fethedilen Kırşehir, önceleri Gülşehri olarak adlandırılmış, daha sonraları ise kent ve çevresi Kırşehir olarak isimlendirilmiştir. Bu isim böylece günümüze kadar değişmeden ulaşmıştır. Malazgirt Savaşı'ndan önce de Kırşehir ve çevresi Türk boyları tarafından yaylak ve kışlak olarak kullanılmış olsa da bölgede Türklerin siyasi otoritesi Anadolu Selçuklu Devleti'nin kurucusu Kutalmış oğlu Süleyman tarafından sağlanmıştır. Ancak bundan sonra Kırşehir ve çevresi yoğun bir biçimde Oğuz-Türkmen boylarının yurt edindiği bir bölge haline gelmiştir (Özüçetin vd., 2014: 91).

Söz konusu Oğuz-Türkmen boylarını oluşturan topluluklar Kırşehir ilinin yerleşilebilir her alanında yurt edinerek ya mevcut köylere yerleşmiş veya yeni köyler kurmuşlardır. Bu köylerden doğrudan Oğuz boylarının adını alan sekiz köy bulunmaktadır. Bunlar; Bayındır, Çepni, Büğüz, Kargınkızıközü, Kargınmeşe, Kargınselimağa, Kargınyenice ve Karkın köyleridir. Ayrıca çalışma alanında Oğuz boylarına bağlı aşiret, cemaat, oymak, taife veya obaların adını alan köy sayısı ise 86 adettir. OğuzTürkmen boylarını oluşturan toplulukların kurdukları bu köylerin isimleri birçok eserde geçmekle beraber özellikle Yusuf Halaçoğlu'nun Anadolu'da Aşiretler, Cemaatler, Oymaklar (1453-1650) adl1 altı ciltlik eserinde yurtları ve bu yurtların yer aldıkları sancak ve nahiyeleri bağlamında da listelenmiştir (Halaçoğlu, 2009). Bunun yanında söz konusu yerleşmelerin adları ve yerleri de belirtilerek Ahmet Gündüz'ün Türkmen Yurdu Kırşehir Tarihi, Aşiretleri, Cemaatleri, Boyları adlı eseriyle, İsmail Uçakçı'nın Oğuz Boyları Aşiret, Oymak, Cemaatler adlı iki ciltlik eserinde geçmektedir (Uçakçı, 2015 a,b; Gündüz, 2006).
Kırşehir ilinde Oğuz-Türkmen boylarını oluşturan aşiret, oymak ve cemaatlerin adlarını alan 86 köyden bazıları şunlardır. Akbıyıklı köyü Döğer Boyu Bıyıklı Aşireti, Alahacılı köyü Bozulus Türkmen teşekküllerinden Alahacılı Aşireti, Aydoğmuş köyü Avşar Boyu Aydoğmuş Aşireti, Boğazevci köyü Bayat Boyu Evci Aşireti, Çadırlı köyleri Bozulus Türkmen teşekküllerinden Çadırlı Aşireti, Çağırkan köyü Beğdili Boyu Çağırgan Cemaati, Çimeli köyü Beğdili Boyu Çimeli Cemaati, Çoğun köyü Bayındır Boyu Çoğun Cemaati, Dedeli köyü Alayundlu Boyu Dedeler aşireti, Demirli köyü Dulkadirli Türkmenlere bağlı Salmanlı Aşireti'nin kolu olan Demirli Aşireti, Dulkadirli köyleri Dulkadirli Türkmenleri, Eldelekli köyleri Bayat Boyu'na bağlı Eldelek Aşireti, Hamurlu köyleri Avşar Boyu'na bağlı Hamurlu Cemaati, Haydarlı köyü Bozulus Türkmen teşekküllerinden Haydarlı Aşireti, Karacalı köyü Yazır Boyu Karacalı Aşireti, Karalar köyü Karaevli Boyu Karalar Aşireti, Kılıçlı köyü Beğdili Boyu Kılıçlı Aşireti, Köşker köyü Avşar Boyu Köşker Aşireti, Pekmezci köyü Kızık Boyu Pekmezci Aşireti, Rahmalar köyü Varsak Boyu Rahmanlar Aşireti, Saraycık köyü Eymür Boyu Saraycıklu Cemaati, Savcılı köyleri Avşar Boyu Savcılı Aşireti, Sıdıklı köyleri Avşar Boyu Boynuinceli Aşireti'ne bağlı Sıdıklı Aşireti, Sofrazlı köyü Bayat Boyu'na bağlı Sofraz Aşireti, Tatık köyü Yüreğir Boyu Tatık Cemaati ve Yağmurlu köyleri Karacakurt Aşireti'nin bir alt taifesinin kurduğu köylerden bazılarıdır. Bu köylerin yanında ilde adını bir komutandan veya aşiret beyi gibi Türk aşiretlerince önemsenen bir kişinin adından alan yerleşmeler de bulunmaktadır. $\mathrm{Bu}$ tür köylere Bayramuşağı, Büyük ve Küçükabdiuşağı, Çelebiuşağı, Durmuşlu, Hasanali, Hatunoğlu, Hirfanlar, Kekilliali, Kocabey, Şahinoğlu, Taburoğlu, Topalalioğlu, Uzunaliuşağı ve Yeğenağa örnek verilebilir (Mıstanoğlu, 2004: 86). Söz konusu köylerle ilgili olarak yapılan görüşmelerde köy isimlerindeki kişi adlarının köyü kuran kişiler olduğu belirtilmiştir. Nitekim bu yöntem köy adlarına isim vermede Türk geleneklerine uyan bir tutumdur (Gökyay, 1984: 251; Sakaoğlu, 1984: 259; Koday, 2000: 236).

\subsubsection{Yerleşme Şekilleri İle İlişskili Köy Adları}

Yerleşme faaliyeti, insanların dünyada kendilerine en uygun yaşam alanlarını ve böyle yerlere yerleşmelerini ifade eden bir olgudur. İnsanların dünya yüzeyinde kendilerine yaşam alanı olarak seçtikleri alanlar rastgele seçilmemiştir. Aksine insanlar yaşamları için elverişli koşullara sahip alanları bulmuşlar ve buraları yerleşim yeri olarak seçmişlerdir (Özçağlar, 2009: 74). Yerleştikleri birimlerin önemli bir kısmı kırsal yerleşmelerden oluşurken bir kısmı da kentsel yerleşme birimleridir. Kırsal yerleşmeler olan köy ve bağlılarında temel geçim kaynağı 
birincil sektörler olurken kentsel yerleşmelerde ikincil ve/veya üçüncül sektörler baskındır. Bir yerleşmeyi tanımlamak üzere kullanılan köy, kent ve şehir kavramlarını adında bulunduran köyler bir yerleşme şekli olmasa da adında köy, kent veya şehir sözcükleri bulunan köyleri kategorize ederken Yerleşme Şekilleri İle İlişkili Köy Adları başlığı altına alınmasının uygun olduğunu düşünmekteyiz. Bu grupta değerlendirdiğimiz toplam 25 köy yer almaktadır. Bunlar içerisinde köy, kışla ve ağıl gibi geçim kaynă̆ının da ne olduğunu belirten köy adlarına sahip olanlar çoğunluktadır.

Türkiye'de kırsal yerleşme birimlerinden bazıları sürekli bazıları da dönemlik olarak kullanılmışlardır. Daimi kırsal yerleşmelerini ana hatlarıla köy, mahalle, mezra ve çiftlik olarak gruplandırırken dönemlik kırsal yerleşmeleri de yayla, kom, oba, dam, ağıl, bağ-bahçe yerleşmeleri biçiminde değerlendirebiliriz (Taş, 2016: 184, 216). Daimi kırsal yerleşmeler içerisinde değerlendirilen yerleşme birimleri içerisinde köy, çiftlik sözcüklerini adında barındıran köy sayısı 10'dur. Bunlar; Acıköy, Alanköy, Avcıköy, Başköy, Çiftlikmehmetağa, Çiftliksarıkaya, Dağçiftliğiköyü, Tepeköy ve Kaman ile Mucur ilçelerinde yer alan Yeniköy'dür. Daimi yerleşmelerde genellikle tarım faaliyetleri ön planda iken dönemlik yerleşmelerde ise daha çok hayvancılık faaliyetleri ön plandadır. Ancak bazı dönemlik olarak kullanılan yerleşmelerin zaman içinde devamlı iskâna tâbi olarak sürekli yerleşme özelliği kazandığı ve ana geçim kaynağının da tarıma geçtiği görülmektedir. $\mathrm{Bu}$ durumdaki köylere örnek olarak çalışma alanımızdaki Akçaağıl, Büyükkışla, Ecikağıl, Kızılağıl, Kuruağıl, Küçükburunağıl, Tatarilyaskışla, Tatarilyasyayla ve Yeşiloba verilebilir. Bunlar daha önceleri hayvancıllk faaliyetleri için dönemlik olarak kullanılırken zamanla kullanım biçimi değişmiş ve sürekli yerleşme özelliği kazanmışlardır.

Arkaç, davarların açıkta toplu olarak yattıkları yer anlamında tanımlandığı gibi düz dağ sırtları anlamında da kullanılmaktadır (TDK, 2009a: 309). Çatalarkaç ve Karaarkaç köylerinde küçükbaş hayvancılığın geçmişte önemli oranda yapılıyor olması adını bu faaliyete bağlı olarak aldığını göstermektedir. Yurt sözcüğü bir halkın üzerinde yaşayarak kültür yarattığı toprak parçası, vatan, memleket, diyar olarak tanımlansa da halk ağzında Yörüklerin yazın veya kışın oturdukları yer anlamında da kullanılmaktadır. Alan ise ülkemizde düz, açık, geniş yer, meydan, saha anlamlarına gelecek biçimde kullanılmaktadır. Alanköy, Güzyurdu ve Yeşilyurt köylerinin adlarında hem geçmişteki Yörük kültürü hem de hayvancılık fonksiyonu saklıdır. Çevirme köyünün adının etrafı duvarla veya çitle çevrilmiş küçük bahçe anlamında kullanılan çevirme sözcüğünden gelmesi muhtemel olup buranın daha sonraları göçle büyüyerek köy haline geldiği değerlendirilebilir (TDK, 2009b: 1152).

\subsubsection{Dini Unsurlar İle İlişkili Köy Adları}

Dünyanın birçok kesiminde yer adı olarak dinsel adlar sık görülmektedir (Aksan, 1982: 116). Kentsel yerleşmelere göre kırsal yerleşmelerde adlandırma konusunda dinsel öğelerin biraz daha fazla yaygın olduğunu söyleyebiliriz. Bu duruma kırsal kesimde daha kapalı bir sosyolojik yapının tesir etmesi muhtemeldir. Kırşehir'de dini unsurlar ile ilişkili köy adı sayısı 12'dir. Bunlar sadece hac1, hoca, fakı ve molla olmak üzere dört kavramla karşımıza çıkmaktadır. Bunlar içerisinde en fazla da hacı ismi alanlar olmuştur. Kırşehir'de hacı ismi alan beş, fakı ismi alan dört, hoca ve molla ismi alan birer köy yer almaktadır. Çalışma alanında hacı ismini alan köyler; Hacıhasanlı, Hacımirza, Hacıselimli, Hacıoğlu, Ömerhacılı'dır. Hoca unvanını alan İsahocalı ve molla unvanını alan Mollaosmanlar köyü dışında bu unvanlara sahip başka bir yerleşme yoktur. Bunlara ek olarak Hacıfakılı köyünün isminde ise hem hacı hem de fakı sözcüğü yer almaktadır. Fakı, hoca ile müezzin anlamına gelen bir sözcük olup Anadolu'da bu ada sahip birçok yerleşme vardır (Çağbayır, 2007: 1541). Ancak fakının hoca dışında soylu anlamına da geldiği görülmektedir (TDK, 2009f: 4504). Fakat fak1 sözcügünün bu anlamda yörede kullanılmaması bu köy adlarının orada yaşamış bir dini önderle ilgili olduğunu göstermektedir. Çalışma alanında fakı ismini alan köyler; Derefakılı, Fakılı, Kösefakılı ve Tepefakılı'dır.

\subsubsection{Sosyal ve Kültürel Değerler İle İlișkili Köy Adları}

Kırşehir ilinde sosyal kültürel değerlerle ilişkili toplam 11 köy adı bulunmaktadır. Bu adlardan bazıları eşya veya aletle ilgiliyken bazıları da beğeni gibi kişiye ilişkin değerlendirmelerle ilgilidir. Beşikli, Kilimli, Kuşaklı, kalınca bükülmüş ipek iplik anlamındaki İbrişim köyleri, adlarını eşyalardan almış köylerdir. Gümüşkümbet, Mahsenli ve Kesikköprü köylerinin adları yapılardan gelmektedir. Ancak Gümüşkümbet adının kaynağı, rivayetlere göre yapıyla ilgili olduğu yönünde olsa da kümbet sözcügünün tepe anlamı da taşıması, köyün adının yaslandığı tepeden alması olasılığını da doğurmaktadır. Kesikköprü ise adını köydeki Selçuklu döneminde yapılmış olan 13 gözlü köprüden almaktadır. Mahsen veya mahzen ise yapılarda bulunan yeraltı deposu veya eskiden kamu vergilerinin saklandığı yer anlamına gelmektedir (Çağbayır, 2007: 3023) Ancak Mahsenli köy adının kaynağının bu bilgilere dayandığını doğrultacak bir belge yoktur. Geyicek; süslü, güzel, zarif, şı 
kimse (TDK, 2009c: 1995), yaban elması ve küçük geyik anlamlarına gelmektedir (Çağbayır, 2007: 1695). Yetikli ise büyümüş, irileşmiş, yetişmiş, olmuş, bilgili, olgun, ağırbaşlı anlamına gelmektedir. Ancak İbikli, Benzer, Geyicek ve Yetikli köy adlarının kaynağını doğrulatmak mümkün olamamıştır.

\subsubsection{Geçim Kaynakları ve Meslekler İle İlişkili Köy Adları}

Bir bölgede baskın bir şekilde yürütülen ve çevresini de etkileyen bir ekonomik faaliyet türü o alandaki yer adlarında kendini gösterebilmektedir. Kırsal bölgelerde temel geçim kaynağ 1 doğal olarak topraktan ve hayvanciliktan elde edilen hammaddelere bağlıdır. Ancak buna rağmen şehir merkezine uzak uygun bir lokasyonda bulunan bazı köylerde demircilik, nalbantlık, semercilik, ahşap işçiliği veya taş işçiliği gibi zanaat dalları ünlenmiş olabilmektedir. Bu sebeple köy adları bunlardan esinlenerek verilebilmektedir. Kırşehir'de bu kapsamda üç köy bulunmaktadır. Bunlar; Çubuktarla, Özbağ ve Demirci'dir. Çubuktarla'nın eski ismi Veletli olup Yörükan taifesinden bir koldur (Türkay, 2001: 643). Çubuktarla ve Özbağ’ da yürütülen temel etkinlik tarım olduğundan bu ismi almış olmalılar. Nitekim Özbağ günümüzde de bağ ve bahçe tarımının önemli oranda yapıldığı bir yerleşmedir. Demirci köyünde ise köy adı geçmiş dönemdeki zanaat dalına yönelik bir atıfla bulunmaktadır.

\subsubsection{Yer ve Konum Özellikleri İle İlișkili Köy Adları}

Kırşehir ilinde yer ve konum özellikleri ile ilişkili dokuz köy yer almakta olup bu gruptaki köy oranı toplam $\% 3$ gibi düşük bir seviyededir. Çalışma alanında yer özelliği gösteren Boyalık, Harmanaltı ve Yazıyolu olmak üzere üç köy bulunmaktadır. Ancak bunlardan Harmanaltı köyünün eski ismi, Şuayip adlı bir kişiye dayanırken Yazıyolu'nun eski adı olan Hacıaraplı, Dulkadirlilere bağlı Araplu cemaatinden gelmektedir (Gündüz, 2006: 70-71). Kırşehir ilinde konum özelliğini yansıtan altı köy bulunmaktadır. Bunlardan Ortahaciahmetli köyü hariç geri kalanının konum durumu yukarı ve aşağı sözcükleri ile ortaya konulmuştur. Aşağı, orta ve yukarı ön ada sahip olan köylerin birbirlerinde ayrılarak geliştikleri sonucuna ulaşmış bulunmaktayız. Bu bağlamda bu köyler paralel ada sahip olan köy durumundadırlar.

\subsubsection{Tarihsel Geçmiş İle İlişsili Köy Adları}

Anadolu, coğrafi konumunun bir sonucu olarak eski dünya kıtaları arasında doğal bir köprü görevi görmektedir. Dolayısıyla Anadolu, konumundan dolayı her zaman insanoğlunun ilgi odağında kalmıştır. Nitekim Paleolitik, Mezolitik ve Neolitik dönem yerleşmelerinin sayıca fazla oluşu bu durumu net bir şekilde ortaya koymaktadır. Kırşehir Orta Anadolu'da yer alan ve Kalkolitik dönemden günümüze kadar kesintisiz bir biçimde iskân edilmiş bir bölgedir. İlde bu uzun geçmişi adında yansıtan yedi köy bulunmaktadır. Bu köylerden üçünün adında hüyük, üçününkinde kale ve birininkinde de ören adı geçmektedir. Türkiye'de yer alan adında viran veya ören sözcügü bulunan köylerin bazılarının tarihi çok eskilere dayanırken bazılarının tarihi geçmişi fazla değildir. Nihayetinde bu yerler çeşitli sebeplerle terkedilmiş ve yıkılmış olan yerleşmelerdir. Genellikle tarihi geçmişi çok eskilere dayanan ve çoğunlukla ören olarak adlandırılan yerleşmelerin etrafında köprü veya önemli mimari kalıntılar bulunmaktadır. Karacaören köyünde böyle yapıların bulunmaması buranın daha ziyade ekonomik amaçla kullanılmış ve sonra da ekonomik niteliği bir şekilde ortadan kalkmış, bunun sonucunda da terkedilmiş veya sonradan yıkıntıların bulunduğu yerlerde yeniden oluşturulmuş olan bir yerleşme olduğunu göstermektedir. Höyük veya hüyükler tarih boyunca çeşitli sebeplerle yıkılan yerleşme birimlerinde, yıkıntıların üst üste yığılmasıyla oluşan ve çoğu kez tepe içinde yapı kalıntılarının gömülü bulunduğu yayvan tepelerdir. Kırşehir ilinde adında hüyük sözcüğü geçen üç köy yer almaktadır. Bunlar Güllühüyük, Külhüyük ve Hashüyük'tür. Bu hüyüklerden çeşitli dönemlere ait seramikler ve çanak çömlek parçaları elde edilmiştir (Ünsal ve Poyraz, 2017: 602-605).

\subsubsection{Diğer Özellikler İle İliş̧kili Köy Adları}

Kırşehir ilinde anlamına ulaşamadığımız veya herhangi bir kategoriye koyamadığımız köy adları sayısı 12 olup bu da toplamın ancak \%5'i etmektedir. Söz konusu köyler; Büyükteflek, Çamalak, Çopraşık, Eskidoğanlı, Güzler, Kırdök, Küçükteflek, Medetsiz, Seyrekköy, Tosunburnu, Yenidoğanlı ve Yürücek köyleridir. Bazı yerlerde yabancı kökenli bir yerleşme ismi, Türkçeye uyarlanarak ses özellikleri değiştirilebilmektedir (Umar, 1993: 831). Dolayısıyla bazı köylerin adının anlamına bu bağlamda ulaşamıyor olmamız muhtemeldir. Çamalak çam+alak biçiminde birleşmiş olabilir. Alak sözcüğü ise Derleme Sözlüğünde sığır konulan, üstü açık kenarı çitle çevrili yer anlamındadır (TDK, 2009a: 189). Tef Derleme Sözlüğünde in olarak açıklanmış olup Büyük ve Küçükteflek köyünün adının bununla bir ilgisi olabilir (TDK, 2009e: 3860). Bunun dişında Yürücek köyünün adının Yörük'ten gelmesi de olasıdır. Yeni ve Eskidoğanlı köyleri ise Bozulus Türkmen Teşekkülleri içerisindeki Araplı aşiretinin kurduğu Araplıatik ve Araplıcedit köylerinin yeni adlarıdır. Bu köylerin dışındaki Çopraşık, Güzler, Kırdök, Medetsiz, Seyrekköy ve Tosunburnu köylerinin adlarının anlamları ve kaynağı konusunda bilimsel yeterliğe sahip dayanak elde edilemediği için açıklama yapmak uygun olmayacaktır. 
Çalışmanın yöntem kısmında birleşik sözcüklerin sınıflandırılmasında izlenen yol belirtilmiş ve sınıflamanın asli olarak baş ögenin durumuna göre yapıldığı belirtilmişti. $\mathrm{Bu}$ bağlamda her ne kadar birleşik sözcüklerden oluşan köyler tek bir gruba dâhil edilmiş olsa da baş ögeyi niteleyen diğer sözcükler üzerinden köy adları baş ögeyi niteleyen veya tamamlayan sözcük üzerinden de sınıflandırılabilir. Çalışma alanında birleşik sözcüklerden oluşan 72 köy adı bulunmaktadır (Tablo 4). Bu anlamda söz konusu köyler iki gruba dâhil olabilecek köylerdir. Çalışmanın bu kısmını tablo olarak verip belirli örneklerle değerlendirmek gerekirse; baş ögenin durumuna göre Ağapınar asli olarak hidrografyayla ilgili olsa da "ağa" sözcüğünden de anlaşılacağı gibi kişi adları grubuna da girmektedir. Esentepe jeomorfolojik unsurlarla ilişkili olan köy grubunda yer almakla birlikte köy adındaki “esen” sözcüğü rüzgârlı bir yer olduğunu da vermektedir. Nitekim saha çalışmalarında bu köyün tepelik alanda olduğu görülmüş ve morfolojinin de etkisiyle hava sirkülasyonuna da açık olduğu gözlenmiştir.

Karaarkaç, Karaova, Karakuyu ve Kızılağıl gibi köy adlarındaki kara ve kızıl sözcükleri aynı zamanda yer ve konum özelliklerini de belirtmektedir. Nitekim Türk tarihinin çeşitli dönemlerinde renklerin yönleri ifade etmek için de kullanıldığ 1 bilinmektedir. Dört yönün her birisi ayrı renk ile şekillenmiştir. $\mathrm{Bu}$ renklerden kara,kuzeyi; kızıl, güneyi; gök, doğuyu ve ak, batıyı anlatmak için kullanılmıştır (Küçük, 2010: 195; Kütük, 2014: 162). Bu bağlamda çalışma alanındaki köylerde kara ve kızıl sözcüklerinin toprak renginden bağımsız olarak bu adları almasında yönü belirtmesi olasıdır. Tatarilyaskışla ve Tatarilyasyayla köyleri hem yerleşme şekilleriyle ilişkili hem de boy, aşiret, cemaat ve önemli şahıslar ile ilişkili köy adları grubuna girmektedir. Bu örneklerden de görüldüğü gibi birleşik sözcüklerden oluşan köyler iki farklı gruba da girmektedir.

\section{SONUÇ}

Genelde toponimler özelde ise köy adlarıyla ilgili çalışmalar bir bölgenin iskân tarihini, sosyal, kültürel ve ekonomik yapısının yanında coğrafi özelliklerini ortaya koyması açısından oldukça önemlidir. Çünkü toponimler bir ulusun belleği durumunda olup bir ülkenin geçmişini oluşturduğu gibi aynı zamanda bugünü ve yarınıdır. $\mathrm{Bu}$ anlamda başta coğrafyacılar olmak üzere diğer disiplinlerin de yer adları üzerine yapacakları çalışmaları artırması durumunda Türk kültürel coğrafi görünümünün bu topraklarda daha iyi anlaşılması sağlanmış olacaktır. Araştırma sahasını oluşturan Kırşehir ilinde yer alan toplam 255 köy adının \%25'i doğal coğrafya, \%64'ü beşeri coğrafya, \%3'er oranda yer ve konum özellikleri ile tarihsel geçmişi yansıtan adlandırmayla ilgiliyken $\% 5$ 'i ise diğer özellikleri yansıtan adlardan oluşmaktadır. Kırşehir ili köy adları için yapılmış olan bu çalışmada köy adının anlamı ve kaynağına ulaşılamayan, yapılmış olan gruplar içerisine girmeyen veya adının kaynağı ve anlamı hakkında yeterli bilimsel dayanak bulunamayan köy adları bulunmaktadır. Bundan dolayı söz konusu köyler herhangi bir sınıflamaya tabi tutulmayarak diğerleri başlığı altında değerlendirilmiştir. Bu haliyle ildeki köy adlarının \%95'inin kaynağı tespit edilmiştir. Türkiye'deki tüm yer adlarında özelde de Kırşehir köy adlarının incelenmesi ve sınıflandırılması örneğinde olduğu gibi disiplinler arası işbirliği ile çalışmaların yapılması amaca ulaşmada oldukça önemlidir. Bu yolla yerleşme adlarının kaynağının tespiti büyük oranda mümkün olacaktır. Ancak yine de yer adının anlamına ve kaynağına ulaşamama söz konusu olabilmektedir.

$\mathrm{Bu}$ çalışmanın sonuçlarında açıkça görüldüğü gibi Kırşehir'deki köy adlarının ana kaynağı doğal ve beşeri özelliklerdir. Doğal coğrafyayla ilişkili köy adları içerisinde

Tablo 4: Birleşik Sözcüklerden Oluşan Köy Adları.

Table 4: Village Names with Compound Words.

\begin{tabular}{|c|c|c|c|c|}
\hline Ağapınar & Değirmenkaşı & Kartalkaya & Savcılıbağbaşı & Yağmurluarmutlu \\
\hline Alimpınar & Değirmenözü & Kavaklıöz & Savcilıbüyükoba & Yağmurlubüyükoba \\
\hline Altınyazı & Derefakılı & Kızılağıl & Savcılıkışla & Yağmurlukale \\
\hline Asmakaradam & Devepınarı & Karaboğaz & Savcılıkurutlu & Yağmurlusayobası \\
\hline Aşağıhacıahmetli & Doğankaş & Karakaya & Savcılımeryemkaşı & Yaylaözü \\
\hline Aşağıhamurlu & Eldelekliortaoba & Karakuyu & Sıdıklıbüyükoba & Yazıkınık \\
\hline Bahçepınar & Esentepe & Karaova & Sıdıklıdarboğaz & Yeşildere \\
\hline Bayramözü & Gökeşme & Kargınkızıközü & Sıdıklıikizağıl & Yeşiloba \\
\hline Boğazevci & Güllühüyük & Kargınmeşe & Sıdıklıkumarkaç & Yeşilyurt \\
\hline Çalıburnu & Gültepe & Kızıldağyeniyapan & Sıdıklıküçükboğaz & Yukarıçiftlikköyü \\
\hline Çanakpınar & Hanyerisarıkaya & Kurtbeliyeniyapan & Sıdıklıküçükoba & Yukarıhacıahmetli \\
\hline Çiftlikmehmetağa & Harmanpınar & Kuruağıl & Sıdıklıortaoba & Yukarıhamurlu \\
\hline Çiftliksarıkaya & Hashüyük & Ortahaciahmetli & Taşoluk & \\
\hline Dağçiftliğiköyü & Kaleevci & Özbağ & Tatarilyaskışla & \\
\hline Darı̈̈zü & Karaarkaç & Pınarkaya & Tatarilyasyayla & \\
\hline
\end{tabular}


$\% 43$ ile en yüksek oran hidrografyayla ilgili olup bunu \%30'la biyocoğrafya ile ilişkili adlar takip eder. Bu durum doğal coğrafya parametrelerinden su ve canlının adlandırma sürecinde yarı kurak bir bölge olan Kırşehir ilinde ne denli etkili olduğunu göstermektedir. Kırşehir yarı kurak bir bölgede yer aldığından insanların önemli bir kısmı su ihtiyacını yeraltı kaynaklarından karşılamaktadır. Nitekim bu durumu yansıtacak şekilde pınar ve türevi bir ifadeye sahip hidrografyayla ilişkili köy adları içerisinde Ağapınar, Alimpınar, Bahçepınar, Çanakpınar ve Devepınarı gibi birçok köy bulunmaktadır.

Çalışma alanındaki köy adlarını baskın bir biçimde karakterize eden beşeri coğrafya ile ilişkili adlandırmalar içerisinde en yüksek oran \%69 ile boy, aşiret, cemaat ve önemli şahıslarla ilgili olanlardır. Beşeri coğrafya içerisindeki 164 köyün 113’ü bu grupta yer almaktadır. Bu sayı aslına bakılırsa ildeki tüm köylerin neredeyse yarısıdır. Kırşehir geçmişte çok çeşitli topluluklara yurt olmuşsa da bin yılı aşkın bir zamandır Türklerin yerleştiği bir saha olmasından dolayı adlandırmada Türk boyları ve onlara bağlı toplulukların izlerini köy adlarında canlı tutmaktadır. Bunlar arasında Çadırlı, Dulkadirli, Eldelekli, Hamurlu, Kargın, Savcılı, Sıdıklı ve Yağmurlu gibi aşiret ve boy ismini almış birden fazla köy vardır. Nitekim çalışma alanında Kargın Boyu adını alan beş, Savcılı Aşireti adını alan altı, Sıdıklı Aşireti adını alan yedi ve Yağmur Aşireti adını alan beş köy yer almaktadır.

Hakem Değerlendirmesi: Dıș bağımsız.

Çıkar Çatışması: Yazar çıkar çatışması bildirmemiştir.

Finansal Destek: Yazar bu çalışma için finansal destek almadığını beyan etmiştir.

Peer-review: Externally peer-reviewed.

Conflict of Interest: The author has no conflict of interest to declare.

Grant Support: The author declared that this study has received no financial support

\section{KAYNAKÇA/REFERENCES}

Aksan, D. (1982). Her yönüyle dil (ana çizgileriyle dilbilim). 3. Cilt. Ankara: Türk Dil Kurumu Yayınları.

Baykara, T. (1984). Anadolu yer adlarının Orta Asya'daki benzerleri üzerine bir kaynak. Türk Yer Adlarl Sempozyumu Bildirileri. Ankara: Milli Folklor Araştırmaları Dairesi Yay.No.60, Seminer Kongre Bildirileri Dizisi 17, 265-273.

Baytop, T. (2007). Türkçe bitki adları sözlüğü. Ankara: Türk Dil Kurumu Yayınları.

Bulut, İ. (1996). Sorgun yöresi köy ve mevkii adlarının kaynakları. Akademik Araştırmalar Dergisi, I(3), 30-40.

Çağbayır, Y. (2007). Ötüken Türkçe sözlük: Orhun yazttlarından günümüze Türkiye Türkçesinin söz varlı̆ğ. İstanbul: Ötüken Yayınları.
Çürük, Y. (2017). Türkçede birleşik sözcükler (İsimler). (Yayınlanmamış doktora tezi). Ankara Üniversitesi Sosyal Bilimler Enstitüsü, Ankara.

Durbilmez, B. ve Tekin, F. (2014). Nevşehir yöresi yerleşim adları üzerine bir değerlendirme. Folklor/Edebiyat Dergisi, 20(77), 113132.

Emiroğlu, M. (1984). Bolu yöresi yer adları. Türk Yer Adlart Sempozyumu Bildirileri. Ankara: Milli Folklor Araştırmaları Dairesi Yay.No. 60, Seminer Kongre Bildirileri Dizisi 17, 182.

Erinç: (1989). Güneydoğu Avrupa'da Türkçe ekzonimler. İ.Ü Deniz Bilimleri ve Coğrafya Enstitüsü Bülteni, 6, 9-13.

Eröz, M. (1984). Sosyolojik yönden Türk yer adları. Türk Yer Adlarl Sempozyumu Bildirileri. Ankara: Milli Folklor Araştırmaları Dairesi Yay.No.60, Seminer Kongre Bildirileri Dizisi 17, 43-53.

Gökmen, B. (2015). Türkiye'de kadı isimli yerleşmelerin mekânsal analizi: Kadılık kurumunun yerleşme isimleri üzerindeki etkisi. Karatekin Edebiyat Fakültesi Dergisi, 5, (3), 39-64.

Gökyay, O. Ş. (1984). Yer adlarında kişilerin ve olayların payı. Türk Yer Adları Sempozyumu Bildirileri. Ankara: Milli Folklor Araştırmaları Dairesi Yay.No.60, Seminer Kongre Bildirileri Dizisi 17, 243-257. Gülbetekin, M. (2017). Mekânın hafizası yer adları. Ankara: Hitabevi Yayınları.

Gündüz, A. (2006). Türkmen yurdu Kırşehir. Çorum: KaraM Yayınları. Güner, İ., Ertürk, M. ve Bekdemir, Ü. (2000). Iğdır ilindeki yer adlarının kaynakları. Doğu Coğrafya Dergisi, 4, 273-299.

Güney, E. (1996). Toponimik terimlerin sinıflandırılması. Türk Dil ve Edebiyatı Dergisi, 540, 619-630.

Halaçoğlu, Y. (2009). Anadolu'da aşiretler, cemaatler, oymaklar (14531650). Cilt.I-VI. Ankara: Türk Tarih Kurumu.

Hanilçe, M. (2013). Vatan topraklarındaki imza: Türk yer adları, Zile kazası örneği (1455-1575). Turkish Studies, 8(2), 89-135.

İbret, B. Ü. (2003). Çankırı'daki köy adları üzerine coğrafi açıdan bir inceleme. Marmara Coğrafya Dergisi, 7, 53-80.

İzbırak, R. (1989). Sular coğrafyası. İstanbul: Milli Eğitim Gençlik ve Spor Bakanlığı Yayınları.

Koca, N. ve Yazıc1, H. (2011). Afyon ilindeki idari yerleşmelerin toponomik sınıflandırılması. Türk Coğrafya Dergisi, 56, 1-10.

Koday (2000). Trakya'da köy adlarında coğrafyanın etkisi. 28. Coğrafya Meslek Haftası (10-12 Haziran 1998, Edirne), Geçmişte, Günümüzde ve Gelecekte Trakya: Bildirileri. İstanbul: Türk Coğrafya Kurumu. 221-253.

Küçük, S. (2010). Eski Türk kültüründe renk kavramı. Bilig, 54, 185210.

Kütük, A. (2014). İslam/Türk devlet ve toplum geleneğinde renkler ve anlamları. Türkiyat Mecmuası, 24(2), 133-170.

Mıstanoğlu, N. (2004). XIX. yüzyılın ikinci yarısında Kırşehir sancă̆ı. (Yayınlanmamış doktora tezi). Selçuk Üniversitesi Sosyal Bilimler Enstitüsü, Konya.

Özçağlar, A. (2009). Coğrafyaya giriş. Ankara: Ümit ofset matbaacılık.

Özgüç, N. ve Tümertekin, E. (2012). Coğrafya geçmiş kavramlar coğrafyacılar. İstanbul: Çantay Kitabevi. 
Özüçetin, Y. vd. (2014). Kırşehir (siyasi tarihi ve Kırşehir tarihi bibliyografyası). Kırşehir Valiliği İl Kültür ve Turizm Müdürlüğü Yayını, Ankara: Gökçe Ofset Matbaacılık.

Sakaoğlu, S. (1984). İnsan adlarından kaynaklanan yer adlarımız. Türk Yer Adlart Sempozyumu Bildirileri. Ankara: Milli Folklor Araştırmaları Dairesi Yay.No.60, Seminer Kongre Bildirileri Dizisi $17,259-264$.

Sarı, C. (2007). Doğal ve kültürel coğrafya özellikleri açısından beyşehir ilçesi'nde yerleşme adlarının sınıflandırılması. Selçuk Üniversitesi Sosyal Bilimler Enstitüsü Dergisi, 17, 487-501.

Sarı, İ. (2016). Türkiye Türkçesindeki birleşik sözcüklerin merkezlilik odağında sınıflandırılması. Dil Araştırmaları, 18, 199-217.

Sarı, İ. (2018). Eski Türkçede eşmerkezli birleşik sözcük yapıları. Doğan, Ş. ve Güneş, M., S. (Ed). Köktürk Yazısının Okunuşunun 125. Yllında Orhun'dan Anadolu'ya Uluslararası Türkoloji Sempozyumu Bildiriler Kitabı Cilt: 2 içinde (1252-1267). İstanbul: Kesit Yayınları.

Şahin, G. (2010). Türkiye'de yapılmış toponomi çalışmaları. Adıyaman Üniversitesi Sosyal Bilimler Enstitüsü Dergisi, 3(4), 134-156.

Şahin, İ. ve Köse: (2014). Karaburun silikyeradlarında (mikrotoponimlerinde) görülen coğrafi terimler. Dil Araştırmaları, 14, 171-187.

Tarım, C., H. (1940). Yer adları bakımından Kırşehir. Türklük Milliyetçi Kültür Mecmuası, 2(11), 293-295.

Taş, B. (2016). Türkiye’nin kırsal yerleşmeleri. İstanbul: Yedi Tepe Yayınevi.

Tunçel, H. (2000). Türkiye'de ismi değiştirilen köyler. Fırat Üniversitesi Sosyal Bilimler Dergisi, 10(2), 23-34.

Tümertekin, E. ve Özgüç, N. (2002). Beşeri coğrafya insan, kültür, mekan. İstanbul: Çantay Kitabevi.

Türkay, C. (2001). Osmanlı Imparatorluğu'nda oymak, aşiret ve cemaatler. İstanbul: İşaret Yayınları.
TDK. (2009a). Derleme sözlüğü I. Ankara: Türk Dil Kurumu Yayınları. TDK. (2009b). Derleme sözlüğü II. Ankara: Türk Dil Kurumu Yayınları. TDK. (2009c). Derleme sözlüğ̈̈ III. Ankara: Türk Dil Kurumu Yayınları. TDK. (2009d). Derleme sözlüğü IV. Ankara: Türk Dil Kurumu Yayınları. TDK. (2009e). Derleme sözlüğ̈̈ V. Ankara: Türk Dil Kurumu Yayınları. TDK. (2009f). Derleme sözlüğü VI. Ankara: Türk Dil Kurumu Yayınları. Umar, B. (1993). Türkiye'deki tarihsel adlar. İstanbul: İnk1lap Kitabevi. Uçakçı, İ. (2015a). Oğuz boyları aşiret, oymak, cemaatler 1 bozoklar. İstanbul: Bilge Oğuz Yayınları.

Uçakçı, İ. (2015b). Ŏguz boyları II aşiret, oymak, cemaatler. İstanbul: Bilge Oğuz Yayınları.

Uygur, N. (1967). Yer adlar1. Türk Dili Dergisi, 187, 495-502.

Ünsal, V. ve Poyraz, M. (2017). Kırşehir ve çevresi demir çağ yerleşmeleri. Uluslararası Sosyal Araştırmalar Dergisi, 10(52), 600-606.

Yaşar, O. ve Yaşar, Ö., F. (2010). Ayvacık, Bayramiç, Çan, Ezine ve Yenice (Çanakkale ili) ilçelerinde köy adlarının kaynakları. Uluslararası Sosyal Araştırmalar Dergisi, 3(11), 599-611.

Yavuz: ve Şenel, M. (2013). Yer Adları (Toponim) Terimleri Sözlüğü. Turkish Studies, 8(8), 2239-2254.

Yediyıldız, B. (1984). Türkiye'de Yer adı verme usulleri ye yer adı değişikliklerinin tarihî gelişimi. Türk Yer Adları Sempozyumu Bildirileri. Ankara: Milli Folklor Araştırmaları Dairesi Yay.No.60, Seminer Kongre Bildirileri Dizisi 17, 25-41.

Yıldırım, D. (1984). Coğrafya'dan vatan'a geçiş ve vatan ile göç ediş problemi. Türk Yer Adları Sempozyumu Bildirileri. Ankara: Milli Folklor Araştırmaları Dairesi Yay.No.60, Seminer Kongre Bildirileri Dizisi 17, 157-168.

Yusif, Y. ve Kerimov: (2017). Toponiminin esaslart üzerine bir inceleme. Çev. Serdar Yavuz. Ankara: Asos Yayınları. 
